\title{
On speaker commitment and speaker involvement. Evidence from evidentials in Spanish talk-in-interaction ${ }^{\text {is }}$
}

\author{
Bert Cornillie *
}

KU Leuven, Belgium

\begin{abstract}
In this paper I raise the question of how the concepts of speaker commitment and speaker involvement can be applied to evidential expressions. I therefore explore the distinction between commitment and non-commitment as a binary opposition (cf. Katriel and Dascal, 1989; Kissine, 2008) and show that a choice for a binary opposition leads to a clear differentiation of epistemic and evidential markers. Speaker involvement is different from speaker commitment, in that it is gradable. This notion will be relevant at both a propositional and an interactional level of analysis. At the propositional level, I claim that speaker involvement refers to the speaker's processing of the evidential qualification when presenting a state of affairs. At the interactional level, speaker involvement will be shown to play a role in the online planning of the flow of discourse. In my corpus analysis of the Spanish evidential adverbials al parecer 'apparently' and por lo visto 'seemingly', I will argue that the coparticipant's reply to evidentially qualified propositions is an important methodological tool to examine speaker involvement. Moreover, the monitoring of the evidential dimension in interaction will shed new light on non-commitment (cf. Déchaine et al., 2017).

(C) 2017 Published by Elsevier B.V.
\end{abstract}

Keywords: Speaker commitment; Speaker involvement; Speaker hearer interaction; Spanish

\section{Introduction}

In the literature, the notion of commitment is used in different ways and is applied to several domains of language. Speaker commitment often refers to the commitment to a propositional content (Verstraete, 2001) or to the truth of an asserted proposition, and, hence, involves mental presentations about states-of-affairs and the beliefs that surround these propositions. From a linguistic point of view, speakers express that they are committed to the claim they make (overtly). Yet, speakers can also be committed to presuppositions and thoughts (covertly). In talk-in-interaction speakers are, in one way or another, also committed to the consistency of the flow of discourse, to the interaction with their coparticipants as well as to their well-being or to their face (face-saving strategies). The analysis of commitment to the

\footnotetext{
I I would like to thank the three anonymous reviewers as well as the two guest editors for their critical remarks and suggestions for improvement. Special thanks to the editors/organizers of the workshop on Commitment phenomena at the Université de Neuchâtel. All remaining problems are mine.

* Correspondence to: Department of Linguistics, Blijde Inkomststraat 21 Box 3308, 3000 Leuven, Belgium.

E-mail address: Bert.cornillie@arts.kuleuven.be.
} 
proposition and the analysis of the sequential organization of the discourse go hand in hand, indeed. Finally, speaker commitment can also be understood as commitment to a future course of action (intentions or obligations). In this paper, I will argue that speaker commitment to the propositional content covers a specific set of epistemic and evidential expressions. When it comes to studying talk-in-interaction, the notion of speaker commitment has to be complemented with the notion of speaker involvement with special attention to the hearer/coparticipant.

A focus on interaction must be combined with attention to presuppositions and beliefs, in that interaction engages in building up a shared basis for understanding what is being said. Importantly, the interaction between speech participants obeys to the constraint of consistency. In Gunlogson's (2008:109) words: "making a discourse commitment to $\phi$ sets up a future for the discourse where taking a position inconsistent with $\phi$ is not to be expected" (see also Hamblin, 1971; Stalnaker, 1978). This means that speech participants are heavily involved in adding content (propositions, beliefs) to what other participants are saying. The coparticipant's replies to the speaker's assessments can be seen as discourse commitments and form an important tool to uncover the speaker's stance. In this paper, I will not use the term of "discourse commitment", but will instead focus on speaker involvement in interaction.

The focus of the analysis of commitment and involvement is on evidentiality, a functional category that refers to the mode of access to the knowledge presented. Since evidentiality belongs to the broader domain of epistemicity, epistemic modals will also be addressed. The paper is mainly theoretical, but has also a descriptive part at the end. In the theoretical first half, the question of non-commitment vs commitment will be reviewed so as to apply the distinction to epistemic modality and evidentiality (Sections 2 and 3). In the second half, I will examine how the discourse dynamics between speech participants can contribute to a more comprehensive understanding of speaker involvement and evidentiality in talk-in-interaction (Sections 4 and 5). By conducting an analysis of por lo visto 'seemingly' and al parecer 'apparently', I will show that the role of the coparticipant in involvement attribution cannot be overlooked. Thus, a more refined view of the speaker-hearer dynamics can shed new light to previous commitment accounts of evidentiality and epistemic modality.

\section{The commitment - non-commitment distinction}

De Brabanter and Dendale (2008) offer a detailed overview of the status of commitment in language. They differentiate between three big areas of application: (i) speech act theory, (ii) modality and (iii) formal models of dialogue. Although the focus of this paper is on the domain of modality, more specifically evidentiality and epistemic modality, the insights from speech act theory and formal models of dialogue can help us delimit the function of commitment in qualificational categories as epistemic modality (this section) and evidentiality (next section).

In speech act theory, commitment refers to the strength with which an assertive speech act is made. A classic example is the use of the English verb to promise, as in (1), which, due to its strong illocutionary force, is said to bear strong speaker commitment (cf. Searle, 1969:58; Verhagen, 2000:200-202), whereas other expressions, such as I think, witness a lower degree of commitment.

(1) a. I hereby promise that I will come to see you. (Searle, 1969:58)

b. Speaker A: Do you think John will be coming to the party? Speaker B: Well - he promised. (Verhagen, 2000:200-202)

C. Speaker A: Is Peter coming to the party? Speaker B. Sure, he promised. (Verhagen, 2000:200-202)

By contrast, Katriel and Dascal (1989) argue that speaker commitment is not gradable: i.e. a speaker is either committed to a proposition in that (s)he endorses the truth of that proposition or (s)he is not. The different degrees of illocutionary force are then accounted for in terms of speaker involvement. Their claim is an interesting path the explore, given the fact that the different degrees of commitment are often difficult to underpin, but one has to avoid that the question of commitment vs non-commitment boils down to displacing the problem (to speaker involvement).

Katriel and Dascal (1989) do not clarify the borders between commitment and non-commitment. In what follows, I will first detect the clear cases of non-commitment and then explore whether absence of commitment holds for epistemic possibility, as claimed by Kissine (2008). My claim will be that performative epistemic markers cannot be devoid of commitment. In Section 3, I will then examine whether a similar approach can be followed to study the domain of evidentiality.

Speaker commitment is prototypically correlated with declarative sentences, e.g. (2), whereas non-commitment is prototypically found in questions, in that the latter cannot assert any propositional content, as in (3). The protasis of the conditional does not convey speaker commitment either, since it formulates a possible world, as in (4).

(2) I know him.

(3) Do you know him?

(4) If you know him, can you tell me? 
Now, distinguishing between (2) and (3-4) is quite unproblematic. The distinction may be more challenging when we look at epistemic modality, since an utterance lacking any speaker commitment should be classified as different from one with low commitment. Recall that even low commitment always implies some kind of commitment. In (5), for instance, the speaker shows rather low commitment, but the epistemic downtoning should not be considered as non-commitment. I claim that this is because of the performativity of I think, i.e. the epistemic evaluation is actively endorsed by the speaker.

(5) I think that she will be able to come to see you.

Let us look at the broader domain of epistemic possibility and examine whether it is possible to select a group of noncommitment markers. Epistemic modal expressions typically present a state of affairs that belongs to different possible worlds. Kissine (2008) argues for non-commitment with epistemic possibility, whereas he observes speaker commitment with probability markers, which involve an inferential reasoning process. Yet, the commitment cannot be attributed to the inferential process, given that possibility statements can also be the result of inferential reasoning. In line with Plungian (2001), every epistemic evaluation has an evidential dimension, whereas not all evidentials have an epistemic dimension.

Instead, Kissine (2008) offers a logical account of possibility and probability, as different degrees of epistemic likelihood, based on Toulmin's (1958:55) examples, which are reproduced in (6) and (7). According to Kissine, the possibility reading in (6) does not bear any speaker commitment, which is shown by the felicitous coordination of affirmative and negative possibility, whereas the epistemic adverb probably in (7) does not entail an open state of affairs without any commitment. The infelicitous coordination of affirmative and negative probability is an indication of the speaker commitment.

(6) a. It is possible that John was there.

b. It is possible that John was there and it is possible that he wasn't there

(7) a. John was probably there.

b. *John was probably there, and John was probably not there

Furthermore, Kissine (2008:172) makes an interesting distinction between warranting the truth of a propositional content, as in (7), and deducing the truth, as we observe in prototypical declaratives without any kind of modalization. In (7), a set of beliefs and/or knowledge warrant a proposition with respect to a certain domain, although it is not sufficient to deduce the truth. Nevertheless, Kissine (2008) considers this probably sentence as an assertive speech act, which, hence, conveys speaker commitment. Yet, according to this account, the modal possible expression in (6) does not warrant the truth. I claim that this does not have to do with the modal evaluation in terms of possibility, but rather with the lack of performativity.

Now, the comparison between the test with the adjectival construction in (6) and the test with the adverbial one in (7) is problematic, because probably is used performatively in (7), whereas it is possible that in (6) can convey both a performative and a descriptive reading (cf. Nuyts, 2001). In performative uses, modal markers always bear speaker commitment, whereas markers that are used descriptively do not so, in that they report the modal qualification made by another person. If we repeat the same test with a performative possibly, the coordination turns out to be infelicitous too.

(8) a. John was possibly there.

b. *John was possibly there, and John was possibly not there.

This is in line with Kissine's (2008:159) observation that the same performativity as the one observed in probably is found with "weaker assertive speech acts, such as conjectures or assertions with reservations". With regard to the latter, other expressions, such as modal auxiliaries, in (9), with or without an inferential dimension [ ], then also qualify to bear commitment. A modal auxiliary can also be used in combination with an adversative clause so as to acquire a concessive meaning, as in (10). In this example, the speaker utters the thoughts of the coparticipant. The same happens in the Spanish utterance in (10), where the speaker has recourse to an epistemic adverb to express a main clause with a concessive meaning.

(9) [the light is on.] John may be at home.

(10) You may be right, but I will do it my way.

(11) A lo mejor es un poco grande, pero seguro que este jersey te servirá.

'It may be a bit big, but I am sure that this pullover will help you'

In these three clauses, the speaker conveys an "assertion with reservation", and hence displays speaker commitment. In sum, performative epistemic modal markers express speaker commitment, whereas others do not. It is not the possibility 
in itself that impedes commitment, but the lack of performativity. Even if the sentences present the coparticipant's possible objections in a concessive manner, it is part of the speaker commitment.

In conclusion, the application of the binary opposition between commitment and non-commitment shows that performative epistemic markers convey speaker commitment. Yet, as will be explained in the next section, the case of evidentials will be different. The concept of speaker involvement, not discussed in this section, will be relevant for distinguishing between different evidential values and discourse functions.

\section{The commitment - evidentiality distinction}

Evidentiality is the functional category that refers to the mode of access to the knowledge presented in a clause, which can be sensory, inferential or reportative. Evidentials, unlike epistemic expressions, do not refer to any evaluation of the information, but present the justification of the factual claim (see also Anderson, 1986). Since no evaluation is involved, the distinction between performative and descriptive uses is not at stake with evidentials. Yet, an issue that still needs attention is the question whether the speaker commitment varies according to the evidential values expressed (cf. Palmer, 1986; Nuyts, 2001; Cornillie, 2009; Cornillie and Gras Manzano, 2015). I will show that inferential evidentials can express various degrees of commitment, whereas reportative evidentials do not bear commitment.

In the literature, most accounts state that with reportatives there is no speaker commitment whatsoever. For instance, the French "epistemic" conditionne/ has been analyzed as a non-commitment marker (cf. "non-prise en charge" in Coltier et al., 2009) and a similar account has been presented for its equivalents in other Romance languages (cf. Vatrican, 2015). As for the German auxiliary sollen 'is said to', Faller (2012:300) claims that a speaker using the reportative "does not convey anything about their belief regarding p". Korta and Zubeldia (2014:389) argue that, by using the hearsay marker omen, "speakers assert that the reported proposition has been stated (or written) by someone other than themselves". In their view, the speaker's expression of uncertainty, if it is present, "belongs to the pragmatic content of the utterance and, more precisely, is a generalized conversational implicature of the omen-utterance".

Recently, Déchaine et al. (2017) propose an elegant solution for the non-commitment of reportatives, in that they distinguish between presenting and asserting a proposition. Reportatives only present, but do not assert. More generally, Déchaine et al. (2017) claim that evidentials remain in the Origo Ground, i.e. referring to the mode of access, whereas assertions belong in the Common Ground.

More generally, presentative force gives rise to faultless disagreement. Relevant is the fact that for many sentences marked with evidentials, the prejacent proposition $(P)$ is not part of the Common Ground. Such P's are not-at-issue: $\mathrm{P}$ cannot be challenged or endorsed, but the evidential basis for $\mathrm{P}$ can be. This can be shown in spontaneous utterances involving grammaticized evidentials. When a clause marked by an evidential is challenged, speakers present an alternative $P$ as well as an alternative source of evidence for $P$. This subtle, but systematic, difference in how evidentials are challenged indicates two things: (i) speakers monitor the Origo Ground; (ii) speakers are not committed to the truth-value of the $P$ they present. (Déchaine et al., 2017:31)

Interestingly, such a generalization goes against previous accounts that observe commitment with inferential markers (Van der Auwera and Plungian, 1998, but also Kissine, 2008). This needs further research which goes beyond the scope of this paper.

If we agree that the presence of "discursive otherness" corresponds to the absence of speaker commitment (Lansari, 2008:183), it still has to be tested. Deniability/cancelation is a frequently used diagnostic for testing which propositions are committed to (Murray, 2010; Déchaine et al., 2017:31). But here again, one should be cautious, because the cancelation test can be used in different ways. For instance, the "discursive otherness" of the conditional without commitment, in (12), and the conjectural use of the future, with commitment, in (13) can both be examined by means of the deniability or cancelation test (cf. Celle, 2008:18, 24).

(12) [...] selon un observateur occidental, l'opposition serait également compromise. (Le Monde Diplomatique, 04/1999 in Celle, 2008:24)

'According to a Western observer, even the opposition would be caught up in it'

? 'According to a Western observer, even the opposition would be caught up in it, but I could be wrong about that'

(13) ? The French will be on holiday today, but I could be wrong about that (Palmer, 1979, in Celle, 2008:18)

In these examples, the addition of an epistemic comment focusing on the speaker's own belief state, i.e. but I could be wrong about that is infelicitous, albeit for different reasons. With the conditional, adding the epistemic comment does not work, because there is no speaker commitment. On the contrary, the conjectural future cannot be combined with the adversative sentence because it contradicts the speaker commitment conveyed by the conjecture. 
Moreover, unlike the conjectural future, indirect evidence markers often combine inferential readings with reportative readings; selecting one of the two readings than depends on the context. This is a real challenge, because, in the evidentiality literature, reportative readings are associated with non-commitment, whereas inferences have often been awarded the highest degree of commitment (Van der Auwera and Plungian, 1998, but see Cornillie, 2007 for a discussion). Now, the question is whether the reportative reading of these ambiguous markers corresponds to noncommitment or whether these markers correspond to non-commitment in both the reportative and the inferential reading. My claim is that it is impossible to disambiguate ambiguous evidential expressions in a convincing manner. For example, Spanish parece (ser) que 'it seems (to be) that', in (14), expresses either an inferential conclusion based on shared information or a reportative reading. Hence, parece ser que does not lend itself for a clear differentiation between hearsay and inferential readings.

(14) ¿Cómo pagan hoy los servicios secretos de todo el mundo a sus agentes? ¿Quiénes pagan mejor? - Señor Marina: Bueno, parece ser que la CIA es la que paga mejor. Yo diría que la KGB paga bastante menos.... (España Oral: CDEB033A) (cf. author).

'How do the world's secret services pay their agents? Who is paying the best? Mister Marina: Well, it seems to be that the CIA pays the best. I would say that the KGB pays far less'

In line with the absorbing elements used in mathematics, I claim that non-commitment affects all readings of the marker. As we will see in Section 5, this is in line with the descriptions found in the specialized dictionaries of Spanish particles.

In sum, the binary division into utterances with speaker commitment and others lacking commitment splits the group of evidential expressions into two, with direct evidential and inferential expressions bearing commitment, on the one hand, and reportatives and ambiguous indirect evidentials without speaker commitment, on the other. In the next section, I will examine how the gradable speaker involvement, as proposed by Katriel and Dascal (1989), can be operationalized for the study of evidentiality and other qualificational categories.

\section{Toward an interactional analysis of speaker involvement}

Katriel and Dascal (1989:278) invoke the notion of speaker involvement as a means to evaluate the relation of a speaker with a future action or a propositional content on a scale from weak to strong. They claim that 'the 'stronger' an illocutionary point, the more the speaker is 'involved' in achieving its aim; the stronger a sincerity condition, the more the speaker is 'involved' in expressing the relevant psychological state presented in that condition". Cornillie and Delbecque (2008) argue for a cognitive definition of speaker involvement in terms of the speaker's role in the subjective construal or conceptualization of an expression. Both approaches account satisfactorily for the illocutionary force of interpersonal speech acts such as commands and requests (Katriel and Dascal) and the conceptualization of deontic force (Cornillie and Delbecque), but it is yet to be seen how a similar account can be developed for a qualificational category such as evidentiality. In the remainder of this section I will explore two ways of applying the concept of speaker involvement to evidentials.

First, degrees of speaker involvement can be attributed to the relation between the speaker and the base of the evidential qualification: visual perception and inferences based on direct evidence would then amount to strong speaker involvement, whereas conjectures and inferences based on knowledge or on hearsay would then stand for intermediate speaker involvement. By contrast, hearsay/reportatives correspond to a low involvement, which is no surprise, since evidential markers that lack a speaker-related mode of access entail absence of speaker commitment. Another way of using speaker involvement has to do with the on-line planning of the interactional sequence and, hence, concerns the relation with the hearer or coparticipant. In previous analyses, I have shown that epistemic and evidential markers are often instrumental in the speaker's strategies to involve speech participants, i.e. reaching out to the coparticipant so as to co-construe discourse. Speakers who are in search of confirmation may display a low involvement for strategic reasons, for instance, in order to leave room for involvement by the coparticipant.

All too often degrees of speaker commitment, or, for the purpose of the present paper, degrees of speaker involvement, are mentioned without any discussion about the methodology to be used to analyze them. Yet, the usefulness of the concepts can only be proven on the basis of sound criteria. Several authors look for reformulation tests, as shown in the above-mentioned examples (6-7) and (12-13), so as to test the logical implications entailed by the constructions. In an inspiring attempt to enrich the current tools available, Morency et al. (2008) and Boulat (2015) argue that speaker commitment should be approached through detecting commitment attribution by the hearer. Although they are aware of the fact that commitment can never be completely uncovered, they propose to look for explicit and implicit hearer reactions in the discourse context. Since so far such an analysis of speaker commitment/involvement has not been carried out on the basis of actual data, in the remainder of the paper I will attempt to undertake this endeavor. 
The involvement attribution by coparticipants will be tested by means of an empirical, qualitative analysis on two different levels. First, the basic level is the proposition, where we have the qualificational readings and expression types described in Section 4. As for the speaker involvement at the level of interaction, a speaker can be strongly involved in the interaction with the coparticipant (interactional sequence). Speaker involvement in the flow of discourse can be expressed by means of the same markers used for expressing commitment/involvement with regard to the proposition.

The analysis presented below fits in what is commonly known as the study of cooperative behavior between speaker and hearer (coparticipant). According to Kissine (2008:165), commitment in hearer-speaker interaction works by means of a "belief box". That is, the hearer, or coparticipant, assumes that newly uttered content can be added to what is mutually presupposed to be true, i.e. to the Common Ground (see also Déchaine et al., 2017). I will therefore focus on the coparticipants replies and examine whether speech participants monitor the evidential dimension rather than the proposition itself.

\section{Analysis of speaker and hearer involvement}

In this section I will discuss the role of two Spanish evidential markers in spontaneous speech, namely al parecer 'apparently' and por lo visto 'seemingly'. The study is based on a qualitative analysis of 42 utterances with al parecer and por lo visto in talk-in-interaction (spontaneous conversation, TV talks, radio debates, telephone calls, consultancies). The examples stem from the Corpus oral del español contemporáneo (Corlec), which contains peninsular Spanish from the Madrid area.

The two markers have received quite some attention over the last years and there seems to be a broad consensus about the lack of speaker commitment (Martín Zorraquino and Portolés, 1999:4159; Santos Río, 2003; Val.es.co, Briz et al., 2008). In his Diccionario de partículas, Santos Río $(2003: 491,657)$ defines the semantics of al parecer (AP) and por lo visto (PLV) as "according to contextual cues" (AP) resp. "according to what one sees" (PLV) and "in line with the someone else's opinion of the reports" (AP) resp. "to judge from what is said" (PLV). González Ramos (2005a,b, 2016) has recourse to reformulation tests to describe the distribution and pragmatics of the two markers. She contends that por lo visto is more grammaticalized and more common in colloquial speech than al parecer, which belongs to more formal genres. In the online Diccionario de Partículas Discursivas del Español, Ruiz Gurillo (2008) states that por lo visto refers to a "fact known through an indirect source". In the same Diccionario, Albelda Marco (2008) mentions that al parecer marks that "the speaker is not a direct witness of the reported information."

More recently, Martín Zorraquino (2014) presents a lexicographic description of al parecer and por lo visto stressing that there is no speaker commitment. García Negroni and Libenson (2016:72) claim that the speaker uses por lo visto to "testify to the existence of the perceptual cues from which (s)he starts, of what has been said in a previous utterance, or of the someone else's utterance". Finally, Cornillie and Gras Manzano (2015) examine the discourse functions of the two markers in spontaneous conversation and Estellés Arguedas and Albelda Marco, 2017) discuss the semantics and pragmatics of al parecer and por lo visto in the different genres, concluding that the irony and politeness, which are often associated with the markers, are contextually derived, hence no core readings.

So far commitment or involvement attribution by the coparticipant to the speaker has not been dealt with in the literature, nor has there been any attention to the monitoring of the evidential dimension in the flow of discourse. This is what I will do in the following pages on the basis of five examples, three of por lo visto 'seemingly' and two of al parecer 'apparently'.

In the first example, in (15), the speech participants discuss in a radio debate the news that a bank director was caught with 15 kilos of cocaine. By means of the marker por lo visto, the speaker concludes that the director is a good dealer.

\section{Spontaneous conversation among friends}

$<\mathrm{H} 2>$... kilo y medio de coca, ¿no?

'kilo and a half of cocaine, isn't it?'

$<H 1>$ Con quince kilos.

$<\mathrm{H} 4><$ simultáneo> Quince, quince. Sí.

'Fifteen, fifteen. Yes'

$<\mathrm{H} 2>$ ¡Ah, quince! Ah. Se me... se me había corrido la coma. <todos $><$ risas $>$

'ah, fifteen! Ah. I overlooked the comma'

$<\mathrm{H} 1><$ simultáneo > Sí.

$<\mathrm{H} 4>$ Sí.

$$
\text { 'yes' }
$$

'yes'

$<\mathrm{H} 2>$ Está bien, está bien quince, ¿no?

'it is enough, fifteen is enough, isn't it?' 
$<\mathrm{H} 4>$ Está muy bien. Era un distribuidor de primera línea, por lo visto.

'It is really enough. He was a first class dealer, apparently'.

$<\mathrm{H} 1>$ Pero vamos, si es $<$ palabra cortada $>$... Yo he esta $<$ (d) $>0$ hablando con Fernando Sánchez Dragó sobre... y creo que cualquier persona que piense un poco... eso. Eh. . . Yo le decía el otro día a u<palabra cortada $>$... a una amiga vuestra, a una compañera, Sol Alonso y se... decía: "Pero, ¿tú estás loco?". . Y Yo creo que tiene que haber carné de yonqui. O sea, ¿usted quiere ser yonqui?, ipor qué no va a serlo! Usted con su... cuerpo puede hacer lo que le de la gana, pero que ponga "heroinómano".

'But, let's see, if. . I have been talking to Fernando Sánchez Dragó about. ... And I think that every single person who thinks a bit.... Well-. Eh. TI told a friend of yours, an acquaintance, Sol Alonso, and. . she said: "but are you mad?" .... I think that there should be a junky card. Thus, "you want to be junky? Well why shouldn't you be allowed! You can do with your body what you feel like, but please mention the label "heroin addict"'.

In (15), por lo visto, which goes in sentence-final and turn-final position, is ambiguous: it can convey an inferential or a hearsay reading, or an inferential reading based on hearsay. Following the above-discussed opposition between speaker commitment and non-commitment, the utterance with por lo visto witnesses no speaker commitment here. As for the speaker involvement in the proposition, there is low involvement on the processing level: the inferential conclusion is derived from indirect evidence or the proposition is merely reported. On the interactional level, the coparticipant (H1) takes the turn as a response to the evidential marker. The adversative marker pero in turn-initial position emphasizes that she disagrees with speaker $\mathrm{H} 4$ 's low involvement. In terms of commitment/involvement attribution, the coparticipant questions $\mathrm{H} 4$ 's decision not to give a more personal view and contrasts it with directly experienced evidence presented as hablar con Fernando 'speak to Fernando' and cualquier persona que piense un poco 'everyone who thinks a bit'. Hence, the example shows two important things: (i) speaker $\mathrm{H} 4$ is attributed (too) low attribution by the coparticipant; (ii) speech participants monitor the evidential qualifications without asserting the proposition.

In the spontaneous conversation in (16), speaker $\mathrm{H} 2$ reports on what she has heard about a friend's wedding ceremony. The topic is about whether the type of church is Moorish or Romance.

\section{Spontaneous conversation among friends}

$<\mathrm{H} 1><$ <isas > Oye una cosa, y... el... ¿qué te iba a preguntar yo? ¡Ah!, que dónde se casa.

'hey one thing.. and what did I want to ask? Ah, where will she get married?'

$<\mathrm{H} 2>$ En Toledo, en una iglesia... <fático=duda $>$ mudéjar, creo que me dijo, pero yo creía que roman $<$ palabra cortada $>$...

In Toledo, in a.... Moorish church, I think that she told me, but I thought that it was a Roman...

$<\mathrm{H} 1>$ ¿En Toledo?, ¿pero por qué Toledo?

'In Toledo?, but why in Toledo?

$<\mathrm{H} 2><$ simultáneo> ¡Ah! Pues 'oh, well'

$<\mathrm{H} 1>$ Estaba yo pensando </simultáneo>: "¿En qué calle está eso?" <risas>

'I was thinking "in which street is that?"'

$<\mathrm{H} 2>$ No porque quería... querían una iglesia... románica, pero por lo visto es mudéjar.

'No, because she wanted they wanted a Romance church, but it seems that it is Moorish'

$<\mathrm{H} 1>$ Oye, la gente busca unos caprichos para casarse.

'Jeezes, the people always want to satisfy their whims when they get married'.

$<\mathrm{H} 2>$ Y lo celebra en el Parador <silencio > de Toledo.

'and the party is in the Parador ... of Toledo'

$<\mathrm{H} 1><$ fático=exclamación $>$ Está bien.

'It is okay'

Coparticipant $\mathrm{H} 1$ asks a lot of questions; by using por lo visto speaker $\mathrm{H} 2$ signals that she lacks direct evidence to whether it is really a Moorish church: (i) creo que me dijo 'I think that she told me', (ii) pero por lo visto es mudéjar 'but apparently it is Moorish'. In fact, there is a contrast between her own thoughts and the friend's information. What $\mathrm{H} 2$ does is reporting the inference of a friend who wanted to get married in a Romance Church but came to the discovery that it was a Moorish one. Hence, on the level of the proposition, the utterance with por lo visto in (16) once again witnesses low involvement of the speaker. On the interactional level, there is no direct reply to speaker H2's use of por lo visto; instead the coparticipant comments on the wish to get married in a Romance church, which coparticipant H1 considers un capricho 'a whim'. So, the first part of the utterance can be considered as part of the common ground or shared belief box. In this example, the evidential marker facilitates turn-taking, but no specific involvement attribution by the coparticipant can be attested. 
In (17), speaker and coparticipants are having a family discussion which deals with the requirements for a hunting permit. Here, speaker $\mathrm{H} 7$ has recourse to information provided by other persons. Por lo visto fits well in this kind of discourse settings, which here too invite for other opinions.

$<\mathrm{H} 1>$ Plan

'plan'

$<$ H6> Plan cinegético.

'Hunting plan'

$<\mathrm{H} 1>$ Cinegético.

'hunting'

$<$ H4> Un plan de... de...

'A plan of ... of'

<H6> Un papelito. <simultáneo> Unos papelitos...

'A piece of paper' 'A couple of sheets'

$<\mathrm{H} 4>$ Se supone </simultáneo $>$ de la ...

'One assumes from...'

$<H 7>$ Sí. < simultáneo > Que él fue...

'Yes... which he was'

$<\mathrm{H} 4>$ de la ca<palabra cortada $>$ de las piezas que vas a conseguir.

... 'of the hu.... of the pieces that you will obtain'

$<\mathrm{H6}>$ Ya, ya.

'yes, yes'

$<\mathrm{H} 7>$ Que eso nos lo había dicho a nosotros uno que tiene la Junta de Extremadura pero es... por lo visto ... 'this is what has told us one who belongs to the Junta de Extremadura, but it is... seemingly'

$<\mathrm{H} 4>$ Es...

'it is'

$<\mathrm{H} 7>$ en Extremadura exigen mucho más porque... nos dio el papelito que...

'in Extremadura they are much more demanding because ... he gave us the piece of paper that'

$<\mathrm{H} 4>$ Eso $<$ simultáneo $>$ no tiene que... eso no tiene na $<$ (d) $>$ a que ver con esto.

'this has nothing to do .... Nothing to do with that'

In (17), speaker $\mathrm{H} 7$ clearly makes an inference on the basis of a personal experience (cf. nos dio el papelito 'he gave us a piece of paper') to state that civil servants are more demanding in Extremadura. On the level of the proposition, the speaker is involved in processing the personal experience. On the interactional level, the mitigation strategy of the speaker corresponds to a moderate speaker involvement, which still allows for the coparticipant to be involved. Interestingly, in this case there is clear involvement attribution by coparticipant $\mathrm{H} 4$, in that she rejects the inference by stressing that the association made is not convincing: no tiene nada que ver. Hence in this example too, there is monitoring of the evidential dimension.

Let us now discuss two instances of al parecer 'apparently'. As mentioned before, this marker is more common in formal registers. The examples below confirm the different speaker hearer dynamics. The first example that we present, in (18), is part of a radio programme on medical issues.

Interview to a doctor

$<\mathrm{H} 2>$ Doctor Junco, tenemos aquí una preocupación que es constante y va quedándose a lo largo de programas, eh. . me refiero, desde el punto de vista pediátrico, las alteraciones en la posición de los pies... al nacimiento, al parecer son más o menos frecuentes. ¿Deben ser controlados por el pediatra?

¿Cómo... cómo afrontan ustedes este problema?

$<\mathrm{H} 3>$ Pues es un tema que a veces pasa desapercibido en la exploración física del recién nacido y que... más tarde puede

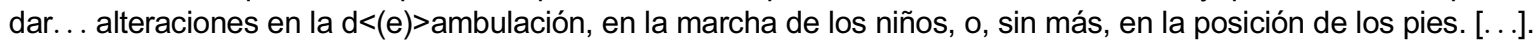

$<\mathrm{H} 2>$ Doctor Junco, we have here a continuous concern that repeats itself throughout the series, eh... I mean, from a pediatrician's point of view, the disorders in the position of the feet. . . at the moment of birth, apparently are more or less frequent. ¿Need they be controlled by the pediatrician? ¿How... how do you cope with this problem?

$<\mathrm{H} 3>$ Well it is a topic that sometimes goes unnoticed in the physical check of the new born and which... later can give... disorders in the way the kids walk or, without further problems, in the position of the feet. [...]. 
The journalist $\mathrm{H} 2$, who is a medical doctor, draws a conclusion from his own experience and has recourse to al parecer to express his inferential statement. On the level of the proposition there is speaker involvement. The evidentially qualified utterance also prepares the scene for two questions, which follow immediately and show that the evidential marker also plays a role on the interaction level. Instead of producing a declarative utterance with speaker commitment, the journalist chooses to lower his own involvement so as to favor the interaction with coparticipant $\mathrm{H} 3$. That this strategy works can be concluded from the temporal reference in both turns: $\mathrm{H} 2$ refers to the disorders that are al parecer más o menos frecuentes 'seem more or less frequent' and $\mathrm{H} 3$ confirms with a veces 'sometimes' and various types of disorders (cf. puede dar alteraciones 'it can give disorders'). From this similarity we can conclude that speaker $\mathrm{H} 3$ endorses $\mathrm{H} 2$ 's involvement. This context does not witness clear involvement attribution by the coparticipant, which probably has to do with the two questions at the end of the turn.

The second example of al parecer in (15) is a special one. First, the evidential marker shows up three times in a long turn of a journalist (Miguel Ángel) who is reporting details of the situation in situ, whereas the coparticipant (Teresa) is in the studio. Second, the marker is used in combination with a series of other qualificational and mitigation markers. Here we observe that al parecer is used to refer to either an inferential conclusion from what third persons told him (first use) or to report what these persons have said (second and third uses). In the three cases, we can detect speaker involvement on the basis of contextual cues, e.g. the sentence como podíamos anticipar antes 'as we made clear before', the emphatic complementizer si que 'really' and the cleft construction lo que realizan es 'what they do is'. These elements are instances of speaker involvement in presenting the proposition. In the reporter's setting, the coparticipant, by contrast, is an outsider who lacks detailed information. There is no interaction with the hearer: on the sequential level, the speaker is involved in organizing his own discourse. (S)he himself varies in the way (s)he presents the different elements of the dossier.

\section{Radio report}

$<\mathrm{H} 3>$ Buenos días Teresa, buenos días a todos los oyentes de nuevo, pues en efecto no se trata de operarios municipales, y sí se trata de... pues personal de una empresa vallisoletana que al parecer, lo que está realizando tampoco es picaresca, como podíamos anticipar antes, en un principio, sino lo que hacen es quizá una técnica de venta un poco agresiva ¿ ¿no? eh... quizá, a lo mejor, alguno de los oyentes que nos llamaba los confundía con operarios municipales, pero evidentemente se trata de ese personal. Lo que realizan es como digo, una técnica quizá algo agresiva de venta de unos, de... de unos filtros depuradores del agua, quizá tomando también como referencia el mal estado del agua en la ciudad, recordemos que se están retrasando esas obras en los depósitos municipales que permitirán en un futuro tener un agua en condiciones, pues quizá aprovechando esas circunstancias, esta empresa lo que está haciendo es mandar a sus vendedores a nuestra ciudad para que visitando los distintos domicilios intenten vender ese... esos... filtros depuradores que al parecer sí que son eficaces, es decir que tampoco es que sea un camelo, el producto que ellos ofrecen, pero lo que ocurre es que esa técnica agresiva pues les lleva, eh... no a engañar o a engañar entre comillas a los posibles compradores porque al parecer lo que realizan es un análisis in situ, en la propia vivienda, de los a<palabra cortada> afectados o de los visitados y bueno, pues quizá tampoco los eh... los oyentes o las personas normales puedan conocer con exactitud de qué se trata con ese análisis porque se hace el echar unas gotas de agua en un reactivo y efec<palabra cortada> efectivamente, cambia de color. [...] Vamos a escuchar sus palabras cuando él nos explicaba que no hay ninguna campaña en marcha del Ayuntamiento y que nos explicaba también, qué es precisamente esa campaña de ventas.

$<\mathrm{Ha}>$ Sí efectivamente el eh... el Ayuntamiento no está haciendo ningún, ninguna campaña, ningún seguimiento especial de... del de la calidad o no del agua en los domicilios particulares, [...]

$<\mathrm{H} 3>$ Hello, Teresa, hello again to all listeners, well it is not about municipality workers indeed, and yes it is about... well staff of a Valladolid-based company which apparently what it is doing is not wiliness, as we made clear before, in principle, but what they do is maybe a selling strategy that is a bit aggresive iisn't it? eh. . . maybe, perhaps, one of the listeners who called us mixed them up with some municipality workers, but it obviously is that staff [of the Company, $\mathrm{BC}]$. What they do, is, as I say, a selling strategy which is maybea bit aggresive of, ... of some water depuration filters, maybe also taking into account the bad water quality in the city, recall that those works in the municipal deposits have been delayed, deposits which in the future will give us good water [lit. in conditions], well maybe taking advantage of these circumstances, what this company is doing is to send its sales people to our city so that during their visits to several houses they can try to sell these depuration filters which apparently are really efficient, that is, it is not a pack of lies this product that they offer us, but what happens is that this aggresive strategy makes them mislead the potential clients or mislead quote unquote because apparently what they do is an analysis in situ, in the house, of the a<palabra cortada $>$ afected or of the visited and in fact, well maybe the listeners or normal persons cannot know exactly what this analysis does, because they throw some droplets in a sample and y real<palabra cortada> really, the color changes. [...] 
We will now listen to his words where he explained us that there is currently no municipal campaign and he also explains what this sales campaign precisely is about.

$<\mathrm{Ha}>$ Yes, the City Hall does not have any campaign, indeed, nor special follow up of the wáter quality in individual domiciles, [...]

The other markers in the turn belong in the domain of epistemic modality (quizá 'maybe') and evidentiality (evidentemente 'obviously'), and, importantly, have been accounted for as devices that are instrumental in keeping the word, without fostering turn-taking (cf. Cornillie, 2010a,b; Gras and Cornillie, submitted for publication; Figueras Bates, 2017). The speaker is involved in an accurate as possible presentation of the facts. Hence, the epistemic and evidential markers are a sign of journalistic caution, as not all facts have been proven.

Examples as (19) illustrate the differences between por lo visto 'seemingly' and al parecer 'apparently': not only register differs, but also their role in the interactional organization of the sequence. Por lo visto is clearly more active in the speaker hearer dynamics than al parecer. As a consequence, it is not surprising that in the turns following the latter no involvement attribution has been attested.

\section{Conclusions}

In this paper, I first offered a detailed discussion of the binary opposition between speaker commitment and noncommitment. The review of the literature has shown that there are differences between epistemic and evidential expressions. The observation that the former engage in an evaluation, whereas the latter present propositions turns out to be crucial in accounting for commitment or non-commitment. Performative epistemic evaluation conveys commitment, presenting reportative markers do not. Pure inferential markers are closer to the former than to the latter. Thus, this paper presents new insights into the commitment of epistemic markers and the non-commitment of some of the evidential makers.

This theoretical review also sheds new light on the question of ambiguous evidential markers in the domain of indirect evidentiality. This is not only relevant for Spanish, but for several other European languages. Since in many contexts it is impossible to distinguish between an inferential or a reportative meaning, ambiguous markers are not considered to convey speaker commitment.

Another innovative element of this paper is the operationalization of the notions of speaker involvement and involvement attribution. This paper has shown how evidential markers convey speaker involvement at the propositional level and at the interactional level. The analysis of involvement attribution by the hearer is "no infallible means of safely attributing commitment to an implicitly conveyed representation" (Morency et al., 2008:199), but the way we examined the replies of coparticipants to evidentially qualified utterances is a step in the direction of more empirical, contextual analysis. Moreover, the point of attribution by the hearer is in line with the claim that speakers monitor the evidential dimension (cf. Origo Ground, as proposed by Déchaine et al., 2017).

Finally, the analysis of interactional data has further refined the existing descriptions of por lo visto and al parecer. Whereas the former marker plays a role in the speaker hearer dynamics, in terms of facilitating turn-taking and allowing for speaker involvement attribution, the latter has a role limited to the internal organization of the turn.

\section{References}

Albelda Marco, Marta, 2008. In: Val.es.co, Briz, et al. (Eds.), Diccionario de Partículas Discursivas del Español. Online dictionary: http://www. dpde.es/

Anderson, Lloyd B., 1986. Evidential paths of change, and mental maps: typologically regular a symmetries. In: Chafe, Wallace L., Nichols, Johanna (Eds.), The Linguistic Coding of Epistemology. Ablex, Norwood, NJ, pp. 273-312.

Boulat, Kirat, 2015. Hearer-oriented processes of strength assignment: a pragmatic model of commitment. Belg. J. Linguist. 29.

Celle, Agnès, 2008. Tense, modality and commitment in modes of mixed enunciation. Belg. J. Linguist. 22, 15-36.

Coltier, Danielle, Dendale, Patrick, De Brabanter, Philippe, 2009. La notion de prise en charge: mise en perspective. Lang. Fr. $162,3-27$.

Cornillie, Bert, 2007. Epistemic Modality and Evidentiality in Spanish (Semi-)auxiliaries. A Cognitive-Functional Approach. Mouton de Gruyter, Berlin-New York.

Cornillie, Bert, 2009. Evidentiality and epistemic modality: on the close relationship of two different categories. Funct. Lang. 16 (1), 44-62.

Cornillie, Bert, 2010a. An interactional approach to evidential and epistemic adverbs in Spanish conversation. In: Diewald, Gabriele, Smirnova, Elena (Eds.), The Linguistic Realization of Evidentiality in European Languages. Mouton de Gruyter, Berlin-New York, pp. 309-330.

Cornillie, Bert, 2010b. On conceptual semantics and discourse functions: the case of Spanish modal adverbs in informal conversation. Rev. Cogn. Linguist. 8 (2), 300-320.

Cornillie, Bert, Delbecque, Nicole, 2008. Speaker commitment: back to the speaker. Evidence from Spanish alternations. Belg. J. Linguist. 22 37-62.

Cornillie, Bert, Gras Manzano, Pedro, 2015. On the interactional dimension of evidentials: the case of the Spanish evidential discourse markers. Discourse Stud. 17 (2), 141-161. 
Cornillie, Bert, Marín-Arrese, Juana I., Wiemer, Bjoern, 2015. Evidentiality and the semantics-pragmatics interface: an introduction. Belg. J. Linguist. 29, 1-18.

De Brabanter, Philippe, Dendale, Patrick, 2008. Commitment: the term and the notions. Belg. J. Linguist. 22, 1-14.

Déchaine, Rose-Marie, Cook, Clare, Muehlbauer, Jeffrey, Waldie, Ryan, 2017. (De-)constructing evidentiality. Lingua 186-187, 21-54.

Estellés Arguedas, María, Albelda Marco, Marta, 2017. Evidencialidad, atenuación y descortesía en al parecer y por lo visto. Influencias del género discursivo. In: Cornillie, Bert, Izquierdo Alegría Dámaso, (Eds.), Gramática, semántica y pragmática de la evidencialidad. Ediciones de la Universidad de Navarra, Pamplona.

Faller, Martina, 2012. Evidential Scalar Implicatures. Linguist. Philos. 35, 285-312.

Figueras Bates, Carolina, 2017. La revelancia de los adverbios evidenciales. In: Cornillie, Bert, Alegría, Dámaso Izquierdo (Eds.), Gramática, semántica y pragmática de la evidencialidad. Ediciones de la Universidad de Navarra, Pamplona.

García Negroni, María Marta, Libenson, Manuel, 2016. Argumentación, evidencialidad y marcadores del discurso. El caso de por lo visto. Tóp. Semin. 35, 51-75.

González Ramos, Elisa, 2005a. Por lo visto: marcador de evidencialidad y sus valores pragmáticos en español actual. Interlingüística 15, 665-673.

González Ramos, Elisa, 2005b. Por lo visto y al parecer: comparación de dos locuciones modales epistémicas de evidencialidad en español actual. Interlingüística 16, 541-554.

González Ramos, Elisa, 2016. Contribución al estudio de la evidencialidad en español actual: los signos por lo visto, al parecer, en mi opinión y personalmente (unpublished doctoral dissertation). Universidad de Zaragoza, Zaragoza.

Gras, Pedro, Cornillie, Bert, 2017. Interactional Motivations for Using Evidential Discourse Markers in Spoken Spanish. The Case of por lo visto and al parecer. (submitted for publication).

Gunlogson, Christine, 2008. A question of commitment. Belg. J. Linguist. 22, 101-136.

Hamblin, C.L., 1971. Fallacies. Methuen, London.

Katriel, Tamar, Dascal, Marcelo, 1989. Speaker's commitment and involvement in discourse. In: Tobin, Yishai (Ed.), From Sign to Text. Benjamins, Amsterdam, pp. 275-296.

Kissine, Mikhail, 2008. Assertoric commitments. Belg. J. Linguist. 22, 155-177.

Korta, Kepa, Zubeldia, Larraitz, 2014. The contribution of evidentials to utterance content: evidence from the Basque reportative particle omen. Language 90 (2), 389-423.

Lansari, Laure, 2008. Commitment: a parameter for the contrastive analysis of be going to and aller+ inf. Belg. J. Linguist. 22, 179-196.

Martín Zorraquino, María Antonia, 2014. Las partículas discursivas en los diccionarios y los diccionarios de partículas discursivas (con referencia especial a desde luego / sin duda y por lo visto). Filología, gramática, discurso. Artículos escogidos (1976-2013). Insitituto Fernándo el Católico, Zaragoza, pp. 31-57.

Martín Zorraquino, Maria A., Portolés, Lazaro J., 1999. Los marcadores del discurso. In: Bosque, Ignacio, Demonte, Violeta (Eds.), Gramática descriptiva de la lengua española. Espasa Calpe, Madrid, pp. 4051-4214.

Morency, Patrick, Oswald, Steve, de Saussure, Louis, 2008. Explicitness, implicitness and commitment attribution: a cognitive pragmatic approach. Belg. J. Linguist. 22, 197-219.

Murray, Sarah E., 2010. Evidentiality and the Structure of Speech Acts. Rutgers University Unpublished dissertation.

Nuyts, Jan, 2001. Epistemic Modality, Language, and Conceptualization: A Cognitive-Pragmatic Perspective. John Benjamins, Amsterdam.

Palmer, Frank R., 1979. Modality and the English Modals. Longman, London.

Palmer, Frank R., 1986. Mood and Modality. Cambridge University Press, Cambridge.

Plungian, Vladimir A., 2001. The place of evidentiality within the universal grammatical space. J. Pragmat. 33, 349-357.

Ruiz Gurillo, Leonor, 2008. Porlo visto. In: Val.es.co, Briz, et al. (Eds.), Diccionario de Partículas Discursivas del Español. Online dictionary: http:// www.dpde.es/

Santos Río, Luis, 2003. Diccionario de partículas. Lusoespañola de Ediciones, Salamanca.

Searle, John R., 1969. Speech Acts. An Essay in the Philosophy of Language. Cambridge University Press, Cambridge.

Stalnaker, Robert, 1978. Assertion. Syntax Semant. 9, 315-332.

Toulmin, Stephen, 1958. The Uses of Argument. Cambridge University Press, Cambridge.

Val.es.co, Briz, et al. (Eds.), Diccionario de Partículas discursivas del Español,

Van der Auwera, Johan, Plungian, Vladimir, 1998. Modality's semantic map. Linguist. Typol. 2 (1), 79-124.

Vatrican, Axelle, 2015. Evidentiality and epistemic modality in the rumor/journalistic conditional in Spanish. Belg. J. Linguist. 29.

Verhagen, Arie, 2000. 'The girl that promised to become something': an exploration into diachronic subjectification in Dutch. In: Shannon, Thomas F., Snapper, Johan P. (Eds.), The Berkeley Conference on Dutch Linguistics 1997: The Dutch Language at the Millennium. University Press of America, Lanham, MD, pp. 197-208.

Verstraete, Jean-Christophe, 2001. Subjective and objective modality: interpersonal and ideational functions in the English modal auxiliary system. J. Pragmat. 33, 1505-1528.

Bert Cornillie is associate professor of Spanish linguistics at the University of Leuven (Belgium). His main research interests are historical and interactional linguistics. He (co-)supervises several research projects in Leuven and is collaborating in international research networks. He has published in international journals and volumes on modality and evidentiality. He has also edited several books and special issues of journals on discourse-grammatical phenomena such as modal auxiliaries, modal particles and discourse markers. 